\title{
INTEGRATED METHODICAL SYSTEM OF FORMATION OF PHYSICAL CULTURE IN SCHOOL STUDENTS
}

\author{
Nematullo Akmalovich Usmanov \\ Independent Researcher Department Of Life Safety Fergana State University, Uzbekistan
}

\section{ABSTRACT}

The article analyzes the methods, indicators that show the characteristics of the mechanisms that form and develop the integrated methodological system of formation of physical culture in school students.

KEYWORDS:- Physical culture, educational tool, practice, integrative approach, spiritual maturity, pedagogical technology, competence.

\section{INTRODUCTION}

It is important to ensure the spiritual and physical perfection of young people in the world, to form a healthy life, physical culture through exercise, that is, sports, a socio-pedagogical phenomenon that has been tested for centuries. Because sport is one of the factors that create ample opportunities for everyone to form a healthy lifestyle, regardless of nationality, race or religion.

Particular attention is paid to the integration of social and economic spheres in foreign countries, the formation of their physical culture in education, the formation of practice in improving the educational process and strengthening the scientific and methodological base in this area. In education, the use of methods aimed at ensuring quality and learning best practices, such as methods that characterize the mechanisms that shape and develop students' physical culture, a system of balancing indicators, overall quality management, quality assurance, key performance indicators, continuous quality improvement.

One of the main tasks in the context of reforms in the field of education in Uzbekistan is to improve the health and physical culture of the younger generation. The new model of education aims not only at the formation of knowledge, skills and abilities in students, but also at the formation of their physical culture, more precisely, first of all, the development of a whole physically healthy person. In this regard, President Mirziyoyev said: "We will continue to attach great importance to the rapid development of sports, encouragement and support of athletes who have achieved high results in international competitions." However, despite the clear definition of the directions for improving the education system, it can be 
CURRENT RESEARCH JOURNAL OF PEDAGOGICS 2(6): 38-42, June 2021

DOI: https://doi.org/10.37547/pedagogics-crjp-02-06-09

ISSN 2767-3278

(C)2021 Master Journals

\section{Crossref do) 81 Google}

Accepted 11 th June, 2021 \& Published 16 ${ }^{\text {th }}$ June, 2021

observed that in recent years the number of adolescents and schoolchildren with low levels of physical and mental health has been increasing.

The pedagogical science and education system of our country has a strategically important task, which is to create all the conditions for education to contribute to the preservation and development, not to disrupt the health of schoolchildren and students. In this case, the social and pedagogical significance of the formation of a culture of health, which prepares students for the realization of their dreams in life, is growing.

The item of improvement of the state youth policy of the Action Strategy for the further development of the Republic of Uzbekistan for 2017-2021 provides for the education of physically healthy, mentally and intellectually developed, independent-minded, patriotic, harmoniously developed people with a strong outlook on life. Decree "On measures to radically improve the system of public administration in the field of physical culture and sports" adopted on March 5, 2018, the tasks set by President Sh.M.Mirziyoev on September 20, 2018 at the meeting on the development of physical culture and sports, 2019 This research work to some extent contributes to the implementation of the tasks set out in the 5 positive youth initiatives and other issues proposed on March 19, 2006.

\section{Materials AND METhODS}

Uzbek scientists F.Khojaev, B.Rahimkulov, A.Kerimov, A.Livisskiy, F.T. Researchers such as Masharipov have conducted research on the formation of students 'physical culture. However, in the above research, the problem of shaping the physical culture of students on the basis of an integrative approach has not been studied as a separate study. We therefore found it expedient to investigate this problem.

\section{RESULTS AND DISCUSSION}

Upbringing is an organized pedagogical process for the purposeful improvement of the individual, which allows a regular and systematic impact on the pupil's personality. It is very important to organize the life and activity of students in a pedagogically correct way in the process of education. In particular, the involvement of students in physical education and sports and ensuring their regular participation will have a positive impact on their upbringing.

As noted at the meeting of the Board of Trustees of the Children's Sports Development Fund of Uzbekistan on March 15, 2013, President Islam Karimov said, nurtures them to be able to overcome courage. Regular participation in sports will change the behavior and lifestyle of our children in a positive way. This means that it should be considered as the leading educational tool in educating our youth to become acquainted with sports.

Physical education is a pedagogical process aimed at the morphological and functional improvement of the human body, for its life

aimed at shaping and improving the basic movement skills, competencies, and knowledge associated with them, which are important.

It is no coincidence that in the harmonious development of physical and intellectual resources of young people, in particular, the widespread use of opportunities for physical culture and sports is identified as one of the main directions of public policy. Because physical culture and sports are a necessary factor for further development and strengthening of these resources. "Physical training and sports are an important factor not only in physical but also in spiritual development. It heals the will, teaches to strive for a clear goal, to endure difficulties with endurance and perseverance. It nurtures in 
CURRENT RESEARCH JOURNAL OF PEDAGOGICS 2(6): 38-42, June 2021

DOI: https://doi.org/10.37547/pedagogics-crjp-02-06-09

ISSN 2767-3278

(C)2021 Master Journals

\section{Crossref do) 81 Google}

Accepted 11 thJune, 2021 \& Published $16^{\text {th }}$ June, 2021

the human heart a sense of confidence, pride and pride in victory.

Exercise not only causes significant biological changes in the body, but also to some extent defines and reconstructs the worldview, moral beliefs, character traits, habits, tastes and other qualities that characterize the spiritual world of a person.

In the process of upbringing, it is necessary to cultivate not only the consciousness but also the feelings of the student, to form in him the moral skills and habits that meet the moral requirements of society to the individual. To achieve this, the student's mind, emotions, and will are influenced.

If any of this is overlooked, the goal will be difficult to achieve. The educational process is led by a teacher. It defines the activities of students, creating conditions for their participation in the social process.

The practical effect of physical education tools in solving educational problems is great. However, exercising, including sports, does not in itself cultivate the desired qualities of a person. In this case, the formation of the moral image of the trainees, the good qualities of their character, only when the teacher or trainer correctly carries out the tasks of pedagogical education in its place.

can become a tool.

Through active participation in the social process, students' independence and creative initiative increase. When activities are organized based on the interests and desires of the student community, a process of student peers and selfawareness occurs in the process. When a student achieves a sense of responsibility to the community for his or her behavior, the performer

Rather, it remains an active participant in the overall work. For effective parenting, it is important to know and take into account the driving force, the source of the parenting process.

This means that as a result of regular physical education and sports activities of students, both the body and the spirit of the child become alert, and his whole body develops in a harmonious way. His mind is occupied only with the love of showing his talent, of winning various competitions.

Education plays an important role in the general pedagogical process. It has the character of formation, management, control of the person, and the tasks set in this regard are solved not on the basis of random actions, but on the basis of pre-determined and well-thought-out plans.

Opportunity to the uniqueness of human physical and spiritual maturity, there are enormous opportunities to address the tasks of mental, moral and aesthetic education in the process of physical education. Solving these tasks not only expands the role of physical education as a factor in the all-round development of the individual, but also directly ensures the success of physical education itself.

The fact that the education system in our country, including physical education as a pedagogical process, is carried out in a direction consistent with our national region, is aimed at cultivating high moral and volitional qualities. Properly organized sports training cultivates moral and volitional qualities such as organization, conscious discipline, initiative and ingenuity.

In any social society, the upbringing of the younger generation is organized on the basis of a specific goal. The purpose of education is determined by the development of social society, its direction of development, the content of social relations. The main purpose of education in the Republic of Uzbekistan today is to bring up a 
CURRENT RESEARCH JOURNAL OF PEDAGOGICS 2(6): 38-42, June 2021

DOI: https://doi.org/10.37547/pedagogics-crjp-02-06-09

ISSN 2767-3278

(C)2021 Master Journals

\section{Crossref do) 81 Google}

Accepted 11 $11^{\text {th }}$ Une, 2021 \& Published $16^{\text {th }}$ June, 2021

mature person.

\section{Conclusion}

Analyzing the content of various pedagogical technologies related to the formation of students' communicative competence requires, first of all, teaching school students the rules of etiquette, because at the heart of these rules of behavior created by humanity are such qualities as kindness and respect for all people. At the heart of integrative relationships lies a special respect and a desire for people to be complimenting each other. In this case, etiquette is reflected in the behavior, manners and appearance of each person, which, in turn, determines the moral and vital norms. The pedagogical significance of ethical categories is defined in the work as follows:

- The leading role of good and evil (good and evil) in the spiritual and moral life; - selfawareness, self-control, teacher's conscience;

- vital (transcendental) values: life, health, peace, love, happiness;

- Qualities necessary for a future teacher duty, freedom of moral choice, as well as the priority of feelings of responsibility, justice, human dignity and worth. The process of moral education requires consideration of integrative components:

- ability to carry out professional activity and its forms;

- an integral feature that reflects the desire and ability to demonstrate their potential for personal success;

- have the skills to successfully operate in society;

- A description of the personality traits that indicate the readiness of future teachers to carry out professional activities.

\section{ReFERENCES}

1. Mirziyoev Sh.M. The work of a nation with a great intention will also be great, its life will be bright and its future will be prosperous. - Tashkent: Uzbekistan, 2019. -B. 36.

2. Хўжаев Ф.Ўсмирлар учун миллий харакатли уйинлар. -Т.: Тафаккур, 2015. Керимов A.F. Яккакураш элементларига эга бўлган харакатли ўйинлар. -Т.: ИТА - ПРЕСС, 2015.

3. Ливисский А.Н Мактабгача ёшдаги болаларни жисмоний маданият назарияси ва методикаси Тошкент: 1995.

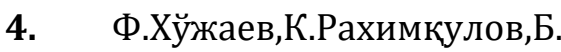

Нигманов.Харакатли уйинлар ва уни ўқитиш методикаси. Ўқув қўлланма.Тошкент:2016. Машарипов Ф.Т. Жисмоний тарбия ва спорт машғулотлари жараёнида ахлоқий тарбия. Илм сарчашмалари. Урганч. 2015. 2-сон, 90-93 бетлар.

5. Зокиров, У. М. Ў., \& Жўраев, Ш. М. (2020). Умумий ўрта таълим мактабларида жисмоний маданият бўйича синфдан ташқари ишларни мониторингини ташкил этиш. Academic research in educational sciences, (3).

6. Шукуров P. С. Талаба-ёшларни жисмоний тарбия ва спорт воситасида соғлом турмуш маданиятини ривожлантириш педагогик муаммо сифатида //Интернаука. - 2020. - №. 28. - C. 85-86.

7. Siddikov, I. В. (2019). Философскопедагогические аспекты развития интеллектуальной культуры студентов. Вестник Ошского государственного университета, (3), 
CURRENT RESEARCH JOURNAL OF PEDAGOGICS 2(6): 38-42, June 2021

DOI: https://doi.org/10.37547/pedagogics-crjp-02-06-09

ISSN 2767-3278

(C)2021 Master Journals

Crossref dof 81 Google

Accepted 11 $1^{\text {th }}$ June, 2021 \& Published $16^{\text {th }}$ June, 2021

38-42.

8. Bakhromovich, Siddikov Ilyosjon, and Maxamadaliev Lutfillo. "Development of ecological culture in students in the process of education of history of uzbekistan." (2021).

9. Bakhromovich, S. I. (2018). Social and philisophical performance of making youth's intellectual culture. European science review, (7-8). 